\title{
Evidence-based guidelines for the management of diabetic foot problems
}

Jonathan Shaw

From Australasian Podiatry Council Conference 2011

Melbourne, Australia. 26-29 April 2011

Management of diabetic foot problems presents a series of complex challenges for patients and for health care professionals. Appropriate guidance on best practice is essential to delivering high-quality care. The NHMRC guidelines for the management of diabetic foot problems in primary care have just been updated to address this issue. The guidelines have been developed using systematic reviews of the literature, and broad consultation of organisations representing the relevant health care professionals and patients. The development of the guidelines, the evidence considered and the recommendations developed will be reviewed.

Published: 20 May 2011

doi:10.1186/1757-1146-4-S1-I11

Cite this article as: Shaw: Evidence-based guidelines for the

management of diabetic foot problems. Journal of Foot and Ankle

Research 2011 4(Suppl 1):111.
Correspondence: jonathan.shaw@bakeridi.edu.au

Baker IDI Heart and Diabetes Institute Level 4, 99 Commercial Road, Melbourne VIC 3004

(c) 2011 Shaw; licensee BioMed Central Ltd. This is an open access article distributed under the terms of the Creative Commons Attribution License (http://creativecommons.org/licenses/by/2.0), which permits unrestricted use, distribution, and reproduction in any medium, provided the original work is properly cited.
Submit your next manuscript to BioMed Central and take full advantage of:

- Convenient online submission

- Thorough peer review

- No space constraints or color figure charges

- Immediate publication on acceptance

- Inclusion in PubMed, CAS, Scopus and Google Scholar

- Research which is freely available for redistribution 